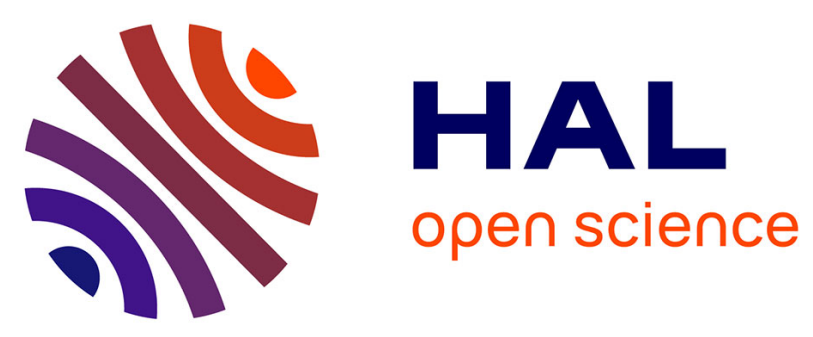

\title{
Does moving to a system with a more generous public health insurance increase medical care consumption?
}

\author{
Léa Toulemon, Laurent Davezies
}

\section{To cite this version:}

Léa Toulemon, Laurent Davezies. Does moving to a system with a more generous public health insurance increase medical care consumption?. LIEPP Working Paper, 2015, 37. hal-01121272

HAL Id: hal-01121272

https://hal-sciencespo.archives-ouvertes.fr/hal-01121272

Submitted on 27 Feb 2015

HAL is a multi-disciplinary open access archive for the deposit and dissemination of scientific research documents, whether they are published or not. The documents may come from teaching and research institutions in France or abroad, or from public or private research centers.
L'archive ouverte pluridisciplinaire HAL, est destinée au dépôt et à la diffusion de documents scientifiques de niveau recherche, publiés ou non, émanant des établissements d'enseignement et de recherche français ou étrangers, des laboratoires publics ou privés.

\section{다(1)(2)}

Distributed under a Creative Commons Attribution - ShareAlikel 4.0 International 


\section{SciencesPo}

LABORATOIRE INTERDISCIPLINAIRE

D'ÉVALUATION DES POLITIQUES PUBLIQUES

\section{LIEPP Working Paper}

February 2015, no37

Health Policy Research Group

\section{Does moving to a system with a more generous public health insurance increase medical care consumption?}

\section{Lauren Davezies}

CREST

laurent.davezies@ensae.fr

\section{Lea Toulemon}

Department of Economics and LIEPP, Sciences Po lea.toulemon@sciencespo.fr

www.sciencespo.fr/liepp

( 2015 by the authors. All rights reserved. 


\title{
Does moving to a system with a more generous public health insurance increase medical care consumption? *
}

\author{
Laurent Davezies ${ }^{1}$ and Léa Toulemon ${ }^{2}$ \\ ${ }^{1}$ CREST \\ ${ }^{2}$ Department of Economics and LIEPP, Sciences Po
}

February 26, 2015

\begin{abstract}
We evaluate the impact of reimbursement rates on health expenditures, using a natural experiment. For historical reasons, reimbursement rates of public health insurance are higher in the French region Alsace Moselle than in other French regions. For both systems, affiliation is compulsory. Individuals moving between $\mathrm{Al}$ sace Moselle and the rest of France undergo an exogenous change in reimbursement rates. We use a difference-in-difference method on a panel dataset of individuals. Our treatment group consists of individuals changing system, our control group consists of individuals who move between other French regions. We study the impact of reimbursement rates on a broad range of health care expenditures: for dentist and doctor visits, drug consumption, and sickness absenteeism. We find heterogeneous impacts of reimbursement rates on those items. Overall, higher public reimbursement rates do not lead to an increase in spending for medical care.
\end{abstract}

Keywords. Public health insurance, health expenditures, natural experiment, moral hazard

JEL codes. I18, D12, C23, H51

*We are grateful to Karen Aissaoui, Mohamed Ali Ben Halima, Eve Caroli, Elise Coudin, Brigitte Dormont, Renaud Legal, Catherine Pollak, Roland Rathelot, Camille Regaert, Etienne Wasmer, two anonymous referees and participants to the TEPP Conference on Research in Health and Labour Economics (Le Mans, 2013), IAAE conference (London, 2014), IHEA conference (Dublin, 2014), EEA Conference (Toulouse, 2014), the LIEPP Graduate seminar for useful comments and suggestions. Hygie data was kindly provided by the Institute for Research and Information in Health Economics. This work is supported by a public grant overseen by the French National Research Agency (ANR) as part of the "Investissements d'Avenir" program (reference: ANR-11-LABX-0091, ANR-11-IDEX-0005-02). 


\section{Introduction}

Faced with the warnings of a committee in charge of monitoring the balance of the National Health Insurance, the French government modifies regularly some parameters of the system such as the reimbursement rates, co-payment or the bundle of health goods and services supported by the system. Such modifications have a direct impact on the reimbursement paid by public insurance (for a given consumption of health care) but they can have more ambiguous effects on consumption, which also matters for the balance of the public accounts.

We measure the causal impact of a change in public reimbursement rate, which does not necessarily imply a decrease in co-payment. Many individuals also have a complementary insurance on top of public insurance. The choice to have complementary insurance is linked with the reimbursement rate of the public insurance. Then, an increase in public reimbursement rate does not necessarily need to lead to a decrease in co-payment. We do not claim to measure price elasticity of demand for medical care. Rather, we measure how, overall, public insurance reimbursement rates impact consumption.

There is a large literature on the impact of reimbursement rates on health expenditures. Comparing people's consumption with heterogeneous insurance to evaluate the effect of generosity of insurance on health care consumption is probably misleading. Indeed, endogenous selection is a critical issue when trying to evaluate the impact of reimbursement rates on health care consumption. There is an incentive for people who expect to need more care to get higher reimbursement rates, by choosing a generous private insurance, or by working for a firm with large reimbursement rates. Since the pioneering theoretical work on asymmetric information in the 70's (Akerlof 1970, Spence 1973, Rothschild \&. Stiglitz 1976) such selection has been widely studied theoretically. Testable implications of such selection have been more recently investigated (Chiappori \& Salanié 2000, Chiap- 
pori et al. 2006, Jullien et al. 2007, Einav \&. Finkelstein 2011) and the empirical literature on such selection in insurance is now quite large (concerning the specific topic of health insurance, we can mention Manning et al. (1987), Million et al. (2003), Buchmueller et al. (2004), Finkelstein \& Poterba (2006), Jones et al. (2006), Schokkaert et al. (2010), Einav \&. Finkelstein (2011), Einav et al. (2013)). Neglecting this issue can lead an overestimate (Manning et al. (1987), Million et al. (2003)) or an underestimate (Jones et al. (2006), Einav \& Finkelstein (2011)) of the impact of increasing health insurance reimbursement rates on heath expenditures.

In the U.S., researchers from the Rand Corporation have addressed this issue using random experiments during the 80's (Manning et al. 1987, Keeler \& Rolph 1988) and more recently (Finkelstein et al. 2012). To our best knowledge such experiments have never been implemented on a large scale in France, and in other countries they are rare for financial and practical reasons.

A second group of studies uses changes in rules of compulsory health insurance to compare health care expenditures before and after the change of rule (for instance, Scitovsky \&. Snyder (1972), Phelps \& Newhouse (1972), Beck (1974), Scitovsky \& McCall (1977) for the U.S.). In France, no less than forty laws since 1976 have changed the reimbursement rules and funding of the National System Insurance, but to our best knowledge only a few academic publications evaluate the causal impact of such reforms, probably because in the absence of control groups, an exogenous change in insurance cannot be distinguished from any other factor that changes over time. A third group of papers use quasi-experiments to evaluate the effect of reimbursement rates on health care consumption controlling for anti-selection, as Chemin \&. Wasmer (2008) did for absenteeism or Chiappori et al. (1998) did for physician services in France. The present evaluation belongs to this last group because our identification strategy relies on a quasi-experiment that we will briefly detail now. However, one should keep in mind that we do not measure the same effect as most 
papers that examine insurance effects. We assess a rise in public reimbursement rates, not a rise in total reimbursement rates, which includes complementary insurances.

For historical reasons, some laws are different in the French region "Alsace Moselle" than in the rest of France. The reimbursement rates of public health insurance are higher, and there is no delay for sickness allowances. Individuals moving in and out the Alsace Moselle local system allow us to distinguish the effect of these local laws from the effect of individual heterogeneity. Because moving itself can also impact medical care consumption, we use movers that move from and to other regions than Alsace Moselle as a control group. We will not estimate a structural model in order to evaluate the impact of the change in a specific price on a specific outcome. Rather we will estimate a reduced form in order to evaluate the global impact of a more generous insurance on various aspects of health care consumption, to give an overall view of how consumption adapts when public reimbursement rates increase. Our outcomes are expenditures for dentist visits, expenditures for doctor visits, drug consumption, and number and duration of sick-leave periods. We find a positive effect on dentist visits, and a negative effect on drug consumption. We find no significant effect on doctor visits and sick-leaves.

Chemin \&. Wasmer (2009) use the Alsace Moselle particular system to evaluate the impact of working-time reduction. They use a Difference-in-Difference strategy on surveys in repeated cross-section to control for regional differences in individual heterogeneity. We use the same setting (Alsace Moselle particularity), but thanks to panel data we use a different method to control for individual heterogeneity.

Here the affiliations to the two systems (national and local) are compulsory given your place of work. Our quasi-experiment is valid as long as people do not choose to move to Alsace Moselle in order to benefit from higher reimbursement rates. Such an assumption could be questionable for close migrations. To check if our results are not led by endogenous selection, we conduct a robustness check without close migrations (individual who move 
to or from neighboring regions). Results are unchanged.

When public reimbursement rates increase at the market-wide level, and demand increases, in the long run the supply of healthcare is likely to adapt to the rise in demand -more physicians are willing to enter the market, and they will adopt new practices (Finkelstein 2007). This spillover strengthens the initial rise in demand implied by higher reimbursement rates. A change in public reimbursement rates is also likely to impact the content of packages offered by complementary insurances. Those impacts are hard to capture with a randomized experiment as the RAND Health Insurance Experiment, which increases reimbursement rates of a randomized fraction of the whole population. Opposed to this approach, we compare two regions where reimbursement rates have been high (or low) for a long time, so that the level of supply corresponds to the long-run equilibrium level in each region. When they are non treated (out of Alsace Moselle), our treatment group faces a supply corresponding to a long-run equilibrium with no treatment. When they are treated (in Alsace Moselle), our treatment group faces a supply corresponding to the long-run equilibrium with treatment. Therefore, our results capture general equilibrium effects of the treatment.

Regressing various aspects of health expenditures on the public insurance system, including time-invariant individual effects, we find that when moving to a system with higher public repayment rates, individuals spend more at the dentist and the same amount for doctor visits, they have more numerous periods of sick-leave without, however, any change in the annual number of sick-leave days, and they decrease their consumption of drugs. In our case, overall consumption decreases when individuals move to Alsace Moselle. Our results are in line with the fact that health care consumption in Alsace Moselle is close to the national average (Cours des Comptes 2011), which suggests a moderate effect of higher reimbursement rates on health expenditures. Even if it is not possible to rule out the effect of some unobserved regional specificities, our results are robust to the robustness checks 
and placebo tests we perform to address this issue. In particular, including controls on the supply side using densities of physicians and pharmacies leads to even more provocative results and reinforces our main message: a higher public reimbursement rate does not necessarily lead to higher consumption of medical care.

The paper is organized as follows. In the second section, we present the particularities of public health insurance in Alsace Moselle. In the third section, we discuss our strategy of identification and our estimators. In the fourth section, we describe the data used in estimation. In the two following sections, we present our result and some robustness check. The last section concludes and discuss the policy implication of our results.

\section{Institutional framework}

The territory hereafter named Alsace Moselle is in the North-East of France, and includes one French région, Alsace, and a département, Moselle. They both share a border with Germany. Figure 2, in Appendix, shows the geographical situation of the Alsace Moselle region in France.

\subsection{The origin of the particular status of AM local system}

Between 1870 and 1918, Alsace Moselle was part of Germany, and German laws were implemented, including Bismarck's social laws, as national compulsory health insurance in 1883. When the region became French in 1918, the inhabitants of Alsace Moselle wanted to preserve their public insurance, but France did not have such a national system. Thus, they maintained Bismarck's laws. A system of local laws (Droit local) was implemented, allowing Alsace Moselle to maintain laws that came from the period when the territory was German. This system was temporary at first, and then became permanent in 1991 Cours des Comptes (2011). In 1945, the French national health insurance system was 
implemented. It applied also to Alsace Moselle, and implemented lower repayment rates. In 1946, it was decided that the local system in Alsace Moselle would act as a complement of the national system, allowing repayment rates to be higher in Alsace Moselle.

\subsection{Details about the local laws}

\subsubsection{Complementarity with the local system}

Any individual affiliated to the local system is also affiliated to the national system. The national system repays a given rate. On top of that, the local system repays part of the amount left for people working in Alsace Moselle. The local regime works as a compulsory complementary insurance scheme.

\subsubsection{Conditions to be affiliated}

From 1998 to 2012, people working in Alsace Moselle, no matter the location of their firm's head office, and people employed by a firm whose head office was in Alsace Moselle were benefiting from the local regime. From March 2012, an individual has to work in Alsace Moselle to benefit. For unemployed people, the affiliation depends on their previous employer (Article L235-1 du code de la sécurité sociale). For retired people, the affiliation to the local system is possible if they have contributed long enough to the system. They need to have been affiliated to the local system either five years before they retire, or during ten years among the fifteen before they retire, or during sixty terms.

\subsubsection{Reimbursement rates}

The public repayment rates for dentists and doctors (both specialized and non-specialized) are $70 \%$ for someone affiliated to the general system. Additionally, $20 \%$ are repayed by the local system, so that people working in Alsace Moselle face a $90 \%$ repayment rate. 
Repayment rates are also higher for almost all health care expenditures, including drugs, and hospital care expenditures. For drugs, the rates in both systems vary depending on whether the drug is considered essential. It varies between $15 \%$ and $100 \%$ for both systems, but for most drugs the repayment rate is higher in Alsace Moselle, around $80 \%$ or $90 \%$, when it is between $30 \%$ and $65 \%$ in the rest of France. Those differences are summarized in Table 1. Details about the reimbursement rates of the general and the local system can be found in Appendix.

\subsubsection{Sick-leave conditions}

People affiliated to the local system also benefit from more generous sick-leave policies. The employers in Alsace Moselle must pay the employee his or her allowance from the first day of sick-leave. In the rest of France, there is a waiting period of three days ${ }^{1}$. During those three days, the employer can give benefits to the employee, but it is not compulsory. From the fourth day, the public insurance pays allowances in both cases.

\subsubsection{Pharmacy opening}

In France, excluding Alsace Moselle, one can open a pharmacy only in cities of more than 2,500 inhabitants. In Alsace Moselle, the threshold is 3,500 inhabitants. Then, a new pharmacy can open if there are 4,500 additional inhabitants ${ }^{2}$. As a result, there are fewer pharmacies in Alsace Moselle. There are 25 pharmacies for 100,000 inhabitants, while the French average is 34.9 (in 2010). The departments of Alsace Moselle are the three where the density of pharmacies is the lowest in France, after Guyane, an overseas department where the same threshold of 3,500 applies. In all those departments, this density is close to the legal maximum, so it is likely that the local laws indeed have an impact on the density of pharmacies in Alsace Moselle.

\footnotetext{
${ }^{1}$ Source: http://vosdroits.service-public.fr/F3053.xhtral

${ }^{2}$ Source: http://vosdroits.service-public.fr/professionnels-entreprises/F1377r.xhtrul
} 
Table 1: The national French system and the Alsace Moselle local system

\begin{tabular}{|l|c|c|}
\hline & French national system & Alsace Moselle \\
\hline \hline Dentists visits & $70 \%$ repaid & $90 \%$ repaid \\
\hline Doctors visits & $70 \%$ repaid & $90 \%$ repaid \\
\hline Drugs & $15 \%$ & $15 \%$ \\
Depending on therapeutic value & $30 \%$ & $80 \%$ \\
& $60-65 \%$ & $90 \%$ \\
& $100 \%$ & $100 \%$ \\
\hline Sick-leaves & 3 -days waiting period for & No waiting period, coverage \\
& allowances, which can be & by the employer is compulsory \\
\hline Pharmacy opening & covered by the employer & \\
\hline
\end{tabular}

\subsubsection{Funding}

The local regime is funded by a tax on wages, which fluctuates between 1.5 and $1.8 \%^{3}$, depending on need. If we want to evaluate inter-regional equity, we need to keep in mind that people in Alsace Moselle are the ones paying for their additional and more generous system.

\section{Identification Strategy and Estimator}

The main objective of this paper is to find a credible counterfactual to health care consumption for some individuals. Our idea is to use the panel structure of the data to consider individuals who move in and out of the Alsace Moselle local regime, and compare their consumptions when subject to the national French system, and when subject to a more generous system. Panel data is a powerful tool to control for the bias coming from unobserved variables. People living in Alsace Moselle do not differ only in term of where they live. Their individual characteristics are likely to be both linked with the region and with

\footnotetext{
${ }^{3}$ Between 2000 and 2013, source : Barènes de l'IPP : prélèveñents sociaux, Institut des politiques publiques, avril 2012
} 
their demand for health care, in an unobservable way. For instance, health care preferences, which is unobservable, may vary across regions. Naive comparisons of average health care consumptions in Alsace Moselle and in the rest of France at a given date (cross-section models) leads to estimate the effects of the insurance system together with the effects of individual characteristics. Affiliation to the system is not exogenous because some unobserved variables can be simultaneously correlated with geographic location and health care consumption. The use of panel data models allows us to obtain consistent estimators in the presence of time-invariant omitted variables.

Of course, in such panel data models, the treatment effect of a covariate $X$ on the outcome is identified only for individuals such that $X$ is not time-invariant (Wooldridge (2002) Chapter 10). Moreover, in case of heterogeneity of treatment effects such as in Imbens and Angrist's framework (Imbens \& Angrist 1994), estimated parameters are only the average treatment effects on such individuals. So, in our case, individuals who move in and out of the Alsace Moselle local regime will play a crucial role. We will present how such people differ from the others in terms of observable characteristics in the next section.

Even if we use people moving in and out of Alsace Moselle, there is a risk to attribute to the social security system a change in health care consumption that is due to professional or geographic mobility. Then, it could be misleading to compare individuals moving in and out of Alsace Moselle with individuals staying in the same firm across time. To avoid such a problem our estimators are identified using comparison between individuals moving in and out of Alsace Moselle with individuals experiencing a regional mobility without changing their health insurance reimbursement rates. To use those other movers as a control group, we add in our regression some supplementary dummies to capture an effect of the move before and after it occurs.

We can now turn to the econometric specification of our models. We assume that the 
health care consumption of individual $i$ at year $t\left(y_{i t}\right)$ is such that:

$$
y_{i t}=\beta \mathrm{AM}_{i t}+\sum_{k=-3}^{2} \delta_{k} w_{k i t}+\gamma x_{i t}+\phi_{t}+\alpha_{i}+\varepsilon_{i t} \text {, }
$$

Following this specification, health care consumption depends on observable and unobservable characteristics stable in the time series dimension through the term $\alpha_{i}$. Health care consumption can also depend on macro shocks $\phi_{t}$, for instance due to epidemics. The $x_{i t}$ is a vector of observables that change in the time series dimension, i.e. the status on the labor market and the wage. The effect of the generation is controlled in $\alpha_{i}$. Age is a linear function of generation and period, therefore age effects are controlled by both terms $\alpha_{i}$ and $\phi_{t}$.

Because our strategy of identification relies on people changing system on the occasion of a change of the region of work, we need to carefully control the correlation between health expenditures and the change of region of work. For people changing region of work between the 1 st January of the year $t_{d}-1$ and the 1 st January of year $t_{d}$, the variable $w_{k i t}$ is a dummy variable that takes value 1 if and only if $t=t_{d}+k$. Such controls are used to control for the variation of health care consumption before and after the change of region of work and compare only with other movers when estimating our parameter of interest $\beta$. Indeed, distribution of heterogeneity in individual preference such as risk aversion is probably very different between movers and non-movers.

$\mathrm{AM}_{i t}$ is a dummy indicating if individual $i$ is affiliated to the Alsace Moselle insurance system at time $t$ and $\beta$ is the parameter of interest. The magnitude of $\beta$ is not explained by difference of population characteristics in Alsace Moselle and the rest of France because we control for individuals effect $\alpha_{i}$. Estimation of $\beta$ is close to a Difference-in-Difference estimator using people who change their region of work as a control group and people who change simultaneously their region of work and their affiliation to the Alsace Moselle local 
system as a treatment group. People who never move enter the estimation by contributing to the estimation of the effect of the control variables $\left(\phi_{t}\right.$ and $\left.x_{i t}\right)$.

Last, $\varepsilon_{i t}$ is the effect of unobserved variables and the main identifying assumption of $\beta$ is simply the usual exogeneity assumption:

$$
\mathbb{E}\left(\varepsilon_{i t} \mid \alpha_{i},\left(x_{i t}\right)_{t=2005, \ldots, 2008},\left(A M_{i t}\right)_{t=2005, \ldots, 2008}, t\right)=0
$$

Under a supplementary assumption of independence across individuals, the "within" estimator of $\beta$ is consistent. Medical care consumption across time is likely to be serially correlated. If people consume medical care regularly, with time spaces greater than one year, medical care in a given year is negatively correlated with consumption the year before. For the inference, serial correlation of the dependent variable is taken into account using clusters the individual level (cf. Wooldridge (2002)).

\section{Data and descriptive statistics}

\subsection{Data}

\subsubsection{Content}

We use the Hygie dataset, an administrative database, merging information from the French national health insurance fund,Caisse nationale de l'assurance maladie des travailleurs salariés (CNAMTS), and from the national old-age pension system, Caisse nationale de l'assurance vieillesse des travailleurs salariés (CNAV). The Hygie database contains annual health care consumption of about 554000 individuals, from 2005 to 2008 , together with information about the career. It is a random sample of individuals between 22 and 70 years old in 2005, who have contributed to the national pension fund at least once during their life, and have used the health care system at least once between 2003 and 2005 . The 
dataset includes health expenditures both for individuals affiliated to the Alsace Moselle system and for individuals affiliated to the national system. This dataset has been used to study sick-leave absences (Halima et al. 2011).

\subsubsection{Sample selection}

We restrict the sample to individuals for whom we have information about consumption, working situation and place of work during the four years. We lose about $5 \%$ of the sample, due to missing information about medical care consumption ${ }^{4}$. We need the place of work to determine who is affiliated to the local insurance system of Alsace Moselle. We remove the individuals whose place of work is not always known, $18 \%$ of the sample. Finally, we remove individuals whose occupation is not known for the four years, $14 \%$ of the sample ${ }^{5}$. In the end, the sample is reduced to 335,000 individuals.

\subsubsection{Identifying who benefits from the local regime}

The dataset does not contain affiliation to the local system. Between 1998 and 2012, the employees of a firm whose head office is in Alsace Moselle, whatever the place of work, and the employees working in Alsace Moselle could be affiliated to the local system ${ }^{6}$. Our criteria for affiliation is the county of the firm employing the individual: we consider that someone is affiliated to the local system if and only if he or she is working for a firm in Alsace Moselle, either in Bas-Rhin, Haut-Rlin, or Moselle, the three counties of Alsace Moselle. It is accurate for everyone except someone who does not work in Alsace Moselle

\footnotetext{
${ }^{4}$ The observations deleted can be people who did not consume any medical care for three consecutive years. Under those conditions they would exit the dataset. They can also be people dead or who have moved in a foreign country. As we do not know the reason why each person exits the dataset, we have no reliable measure of the outcomes we want to estimate. Removing them, the effects will be estimated only for people who do not have three consecutive periods of non consumption.

${ }^{5}$ People with no information can be individuals who are public servant for a period, or that they are affiliated to specific retirement systems, and then not included in the national dataset of the CNAV.

${ }^{6}$ We thank Karen Aissaoui, project officer of the local regime, for helpful information about conditions of affiliation
} 
but benefits from the local system because the head office of his or her firm is in Alsace Moselle. For unemployed and retired persons, we have information about the county last employer, which is the criteria for affiliation.

\subsection{Descriptive statistics}

In this section, we present descriptive statistics about health care consumption and individual characteristics.

\subsubsection{Health care consumption in Alsace Moselle}

We give comparative figures for health care consumption of people working in Alsace Moselle, and people working in the rest of France. We use the restricted sample presented in the previous section.

Table 2 presents annual average of the part of expenditures on health care that is repaid by the national insurance system, and annual averages of total expenditure on health care, at the individual level. If one goes to see a general practitioner once during the year and pays 30 euros, the patient's "Total amount" for doctors visits will be the amount considered by public insurance as the base for repayment, 23 euros, plus extra fees if any (dépassements d'honoraires). The patient's "Amount repaid" will be the fraction of the total amount that is repaid by the national public insurance, that is, $0.70 * 23=15.10 €$, irrespective of whether he or she is affiliated to the Alsace Moselle local system. Indeed, the national insurance repays the same amount for everyone, and the Alsace local system repays on top, as a compulsory complementary insurance.

The part reimbursed for each medical procedure (15.10 € in our example) excludes any extra fees varying across physicians. If it changes, it means that the individual consumes more or less medical care, not that the price has changed. This measure allows us to quantify costs for the national insurance. For these reasons, we will use the amount repaid 
Table 2: Health care expenditures and sick leaves

\begin{tabular}{|c|c|c|c|}
\hline & $\begin{array}{l}(1) \\
\text { Alsace Moselle }\end{array}$ & $\begin{array}{c}(2) \\
\text { Rest of France }\end{array}$ & $\begin{array}{c}(3) \\
\text { P-value }\end{array}$ \\
\hline $\begin{array}{l}\text { Amount repaid } \\
\text { Dentists visits } \\
\text { Doctors visits } \\
\text { Specialists visits } \\
\text { Drugs }\end{array}$ & $\begin{array}{c}67.4 \\
76.1 \\
108.7 \\
214.0\end{array}$ & $\begin{array}{c}49.5 \\
62.4 \\
108.2 \\
190.3\end{array}$ & $\begin{array}{l}0.000 \\
0.000 \\
0.055 \\
0.000\end{array}$ \\
\hline $\begin{array}{l}\text { Total expenditures } \\
\text { Dentists visits } \\
\text { Doctors visits } \\
\text { Specialists visits } \\
\text { Drugs }\end{array}$ & $\begin{array}{l}193.9 \\
112.3 \\
168.8 \\
293.0\end{array}$ & $\begin{array}{c}135.9 \\
95.2 \\
167.3 \\
264.6\end{array}$ & $\begin{array}{l}0.000 \\
0.000 \\
0.030 \\
0.000\end{array}$ \\
\hline $\begin{array}{l}\text { Sick-leave periods } \\
\text { Sick-leave days }\end{array}$ & $\begin{array}{l}0.44 \\
11.5\end{array}$ & $\begin{array}{l}0.34 \\
11.0\end{array}$ & $\begin{array}{l}0.000 \\
0.002\end{array}$ \\
\hline $\begin{array}{l}\text { Nb. Ind } \\
\text { Nb. Obs }\end{array}$ & $\begin{array}{l}16342 \\
60,228\end{array}$ & $\begin{array}{c}320,885 \\
1,278,788\end{array}$ & \\
\hline \multicolumn{4}{|c|}{$\begin{array}{l}\text { Amount repaid: average annual amount repaid by the national public insurance, for dentists visits (line 1), } \\
\text { general practitioners (line 2), specialists (line } 3 \text { ), and drugs (line 4). Total expenditures: average annual } \\
\text { amount spent by the individual for medical care use. }\end{array}$} \\
\hline \multicolumn{4}{|c|}{$\begin{array}{l}\text { Column 3: Two-sided p-value of a t-test comparing mean of individuals means over time in Alsace Moselle } \\
\text { with the mean of individual means over time in the rest of France }\end{array}$} \\
\hline
\end{tabular}


for our main estimations.

The total amount spent is higher than the part repaid by national insurance, especially for dental care. This gap is generally shared between the individual and his or her complementary insurance, the share depending on the reimbursement rate of the complementary insurance. Acting as a compulsory complementary insurance, Alsace Moselle local regime repays part of the gap for people affiliated.

Table 2 shows that average annual consumption of medical care are higher in Alsace Moselle, for dentist visits, doctor visit, and drugs expenditures. All those differences are significant (column 3). On the contrary, there is no significant difference for visits to specialists.

Concerning sick day absences, our measures do not include the three first days of sick-leave, because the public insurance does not reimburse anything for those days. The sick-leave periods enter our data only from the fourth day of absence. We use two measures: the annual number of sick-leave periods and the annual number of sick days. People in Alsace Moselle tend to take more sick-leave periods, and more days of sick-leave. The differences are significant.

There are significant difference in medical care use in Alsace Moselle and in the rest of France. The point of our paper is to use a fixed effect model to see how those differences vary when controlling for time-invariant unobserved individual heterogeneity.

\subsubsection{Descriptive statistics about the groups considered}

In our model, we will use three groups of individuals. The first group, hereafter called movers AM, enter or leave Alsace Moselle during the period, and contribute to the estimation of the effect of Alsace Moselle on consumption, to the effect of the move, and to the controls. The second group, called other movers, are movers who move between other regions, never working in Alsace Moselle. They contribute to the effect of the move, and 
to the controls. Individuals in the third group, non-movers, never change their region of work, and contribute to our model only by contributing to the estimation of the controls.

We will present descriptive statistics about those three groups, about their individual characteristics and their use of medical care (Table 3). We present those means only for descriptive purpose.

Table 3 presents comparisons between movers $\mathrm{AM}$, other movers, and non movers.

Movers to or from Alsace Moselle compared to non-movers Columns 1 and 3 of Table 3 shows outcomes for movers $\mathrm{AM}$ and non-movers. Column 5 gives the significance of the difference. There is a significant difference between people moving to or from Alsace Moselle and not moving for all individual characteristics, except for the fraction retired persons. People who change their affiliation to the local system between 2005 and 2008 are five years younger on average. They have less income. They benefit more often from the CMU-C (public complementary insurance for low income levels) the coverage rate is $4.8 \%$, and $2.7 \%$ for people not moving. There are $8 \%$ less women in the group moving to or from Alsace Moselle. People moving to and from Alsace Moselle are less likely to have chronic diseases. People moving between Alsace Moselle and the rest of France spend on average $22 \%$ of their time unemployed, which is higher than the rest of people $(10 \%)$. Those features are linked with the fact that people moving are five years younger on average. However, differences in age explain only part of the difference in unemployment rates. We include a dummy for being unemployed in our model, because this is likely to be correlated with the move. Concerning medical care use, movers AM use less care than the non movers. Differences are significant for all items except dental care. The individuals contributing to our estimates of the impact of higher reimbursement rates are not representative of the general population. Therefore, our results apply only to a particular subpopulation. 
Table 3: Comparing individuals moving from or to Alsace Moselle, moving from and to other regions, and not moving

\begin{tabular}{l|c|c|c||c|c} 
& $\begin{array}{c}(1) \\
\text { Movers AM }\end{array}$ & $\begin{array}{c}(2) \\
\text { Movers }\end{array}$ & $\begin{array}{c}(3) \\
\text { Non-movers }\end{array}$ & $\begin{array}{c}(4) \\
\text { P-value 1-2 }\end{array}$ & $\begin{array}{c}(5) \\
\text { P-value 1-3 }\end{array}$ \\
\hline Women & 40.2 & 42.5 & 47.7 & 0.020 & 0.000 \\
Age & 37.6 & 37.5 & 42.2 & 0.861 & 0.000 \\
Income & 21226.1 & 19241.1 & 23698.3 & 0.000 & 0.001 \\
Cmuc & 4.80 & 6.04 & 2.74 & 0.002 & 0.000 \\
Unemployed & 0.22 & 0.25 & 0.10 & 0.000 & 0.000 \\
Retired & 0.84 & 0.81 & 0.65 & 0.418 & 0.000 \\
Diseases & 0.078 & 0.075 & 0.11 & 0.680 & 0.000 \\
Dentists & 51.9 & 45.7 & 50.8 & 0.000 & 0.277 \\
Doctor & 138.8 & 139.8 & 174.9 & 0.789 & 0.000 \\
Drugs & 140.7 & 146.5 & 196.7 & 0.652 & 0.000 \\
Sick-leaves & 0.31 & 0.27 & 0.36 & 0.000 & 0.001 \\
Sick days & 8.14 & 8.25 & 11.3 & 0.819 & 0.000 \\
\hline \hline Nb. Ind & 2,473 & 32,703 & 299,578 & & \\
Nb. Obs & 9,892 & 130,812 & $1,198,312$ & &
\end{tabular}

Movers AM: have moved at least once from or to Alsace Moselle. Movers: have moved at least once between other regions than Alsace Moselle. Non movers: individual who never move.

P-value 1-2 is the two-sided p-value of a t-test comparing movers AM with other movers (comparison of group means of individual means over time, $\mathrm{t}=4$ ). P-value 1-3 compares movers AM with non movers.

Women: percentage of women. Age: average age in the group. Income: mean annual income in euros. Cmuc: \% benefiting from public complementary health insurance for low income levels. Unemployed: average share of the year spent unemployed. Retired: average share of the year spent retired. Diseases: number of chronic diseases. Dentist denotes the annual amount repaid by the national health insurance for dentists visits, doctor denotes the amounts repaid for doctors (general practitioners and specialists), drugs denotes the amount repaid for prescription drugs, sick-leave denotes the number of periods of sick-leave, sick-days denotes the annual number of sick-leave days.

Source : Hygie 
Movers to or from Alsace Moselle compared to other movers Columns 1 and 2 of Table 3 compare movers AM with the other movers. Column 4 tests the significance of the differences.

Differences in the percentage of women, average income and average fraction of time spent unemployed are significant. Although differences are significant, the magnitude is not high: $3 \%$ difference for unemployment, almost $2 \%$ in the percentage of women. The difference in average income if $9 \%$. There is no significant difference in the prevalence of chronic diseases, and in the proportion of retired persons. The population of people moving to or from Alsace Moselle is more similar to other movers than to non-movers, so the common trend assumption is more credible for the former group of movers than the latter group of non-movers. Concerning medical care use, movers AM go more often to the dentist, and take more sick-leave periods. For other items, the difference is not significant. At this stage, we do not know if medical care use of movers $A M$ is different because of the fact that they spend some periods in Alsace Moselle, or because of different unobserved characteristics. We have seen descriptive statistics about the different groups that are of interest given our estimation method. Now, we will give a more precise description of medical care use of movers AM and other movers, to assess the validity of our estimation method.

\subsubsection{The common trend assumption}

Our paper is based on a Difference-in-Difference method, comparing medical care use of movers AM with medical care use of other movers. Non movers contribute to the estimation of the controls only.

The Difference-in-Difference method we use is based on the common trend assumption: without the treatment, both groups would have followed the same evolution. As our dataset is a panel, we can check if medical care consumption of movers $\mathrm{AM}$ and other movers follow 
the same trend before treatment. Our case is not a standard difference in difference, as treatment does not arise at the same time for everyone. Some individuals enter treatment in 2006, some in 2007, some in 2008. Some individuals exit treatment in 2006, 2007 and 2008, and some both enter and exit.

The common trend assumption, in our case, would be: (1) before they enter treatment, movers $\mathrm{AM}$ entering treatment follow the same trend of medical care consumption as the control group, other movers, before they move, and (2), after they leave treatment, movers AM leaving treatment follow the same trend as the control group, after they move.

The time scale of the trend is the distance to the move (two years before, one year before...) rather the calendar year $(2005,2006 \ldots)$.

Before moving, individuals entering Alsace Moselle and other movers should have similar outcomes. On the right hand side of Equation 1, we add supplementary dummies $w_{k i t}^{\prime}$ corresponding to each possible duration before the move interacted with the fact to be a mover who enters Alsace Moselle. We create a dummy variable taking the value one if an individual is entering Alsace Moselle once during the period and is one year after the move, and zero otherwise. We create another variable for two years after and another variable for three years after. Then, we estimate this augmented model on our sample without movers leaving Alsace Moselle.

$$
y_{i t}=\beta \mathrm{AM}_{i t}+\sum_{k=-3}^{2} \delta_{k} w_{k i t}+\sum_{k=-3}^{-1} \delta_{k}^{\prime} w_{k i t}^{\prime}+\gamma x_{i t}+\phi_{t}+\alpha_{i}+\varepsilon_{i t}
$$

For any individual, the sums $\sum_{k=-3}^{2} w_{k i t}$ and $\sum_{k=-3}^{2} w_{k i t}^{\prime}+\mathrm{AM}_{i t}$ are time invariant and then colinear with the fixed effects. So supplementary normalizations are necessary. Without loss of generality, $\delta_{-3}$ and $\delta_{-3}^{\prime}$ are normalized to zero.

Then in the model derived from Equation 2, a testable implication of the common trend assumption is the nullity of $\delta_{-2}^{\prime}$ and $\delta_{-1}^{\prime}$. The p-value of the joint significance of 
$w_{-2, i t}$ and $w_{-1, i t}$ is 0.67 for dentist visits, 0.31 for doctor visits, 0.46 for prescription drug consumption, 0.46 for the number of sick-leave periods, and 0.51 for the total number of sick-leave days.

An alternative testable implication of the common trend assumption involves individuals leaving Alsace Moselle instead of individuals entering in Alsace Moselle. In that case the supplementary dummies $w_{k i t}^{\prime \prime}$ interact times dummies after the move with the fact to be a mover leaving Alsace Moselle and the model is estimated on the sample without movers entering in Alsace Moselle.

$$
y_{i t}=\beta \mathrm{AM}_{i t}+\sum_{k=-3}^{2} \delta_{k} w_{k i t}+\sum_{k=0}^{2} \delta_{k}^{\prime \prime} w_{k i t}^{\prime \prime}+\gamma x_{i t}+\phi_{t}+\alpha_{i}+\varepsilon_{i t}
$$

After necessary normalization that could be without loss of generality $\delta_{-3}=0$ and $\delta_{0}^{\prime \prime}=0$. The common trend assumption implies that $\delta_{1}^{\prime \prime}=0$ and $\delta_{2}^{\prime \prime}=0$. The p-value of the joint significance of $w_{1, i t}^{\prime \prime}$ and $w_{2, i t}^{\prime \prime}$ in the model derived from Equation 3 is 0.90 for dentist visits, 0.12 for doctor visits, 0.46 for prescription drug consumption, 0.28 for the number of sick-leave periods, and 0.32 for the total number of sick-leave days.

To conclude, the common trend assumption cannot be rejected with our data when we compare the treated group with the control group using observations that correspond to a period of non treatment.

\section{Main Results}

\subsection{Estimation}

We run a panel data model with fixed effects, as presented in section 3. We control for year fixed effects, employment status (employed or unemployed), income, and the impact of changing work location (using all movers). Details about the variables used and the 
default values can be found in the Appendix. Each regression presents the impact of the treatment, being affiliated to the local regime, on one particular health care outcome, namely, expenditures for dentist visits, for doctor visits, for prescription drugs, number of sick-leave periods, and total number of sick-leave days.

Table 4: Effect of the Alsace Moselle local system on medical care use

\begin{tabular}{lccccc}
\hline \hline & Dentist & Doctor & Drugs & Sick leaves & Sick days \\
\hline Alsace Moselle & $5.259^{* *}$ & -1.351 & $-19.81^{* *}$ & $0.0269^{*}$ & 0.503 \\
& $(2.665)$ & $(3.746)$ & $(8.705)$ & $(0.0146)$ & $(0.672)$ \\
unemployed & 0.0215 & $-53.58^{* * *}$ & $-34.40^{* * *}$ & $-0.254^{* * *}$ & $-26.03^{* * *}$ \\
& $(0.662)$ & $(1.470)$ & $(2.942)$ & $(0.00369)$ & $(0.307)$ \\
partly unemployed & $-1.513^{* * *}$ & $-18.64^{* * *}$ & $-10.23^{* * *}$ & $-0.103^{* * *}$ & $-7.672^{* * *}$ \\
& $(0.544)$ & $(1.114)$ & $(2.124)$ & $(0.00324)$ & $(0.185)$ \\
log income & $1.407^{* * *}$ & $-32.06^{* * *}$ & $-25.48^{* * *}$ & $0.0139^{* * *}$ & $-10.97^{* * *}$ \\
& $(0.233)$ & $(0.629)$ & $(1.409)$ & $(0.00128)$ & $(0.138)$ \\
income dummy & $11.07^{* * *}$ & $-268.3^{* * *}$ & $-190.5^{* * *}$ & $-0.108^{* * *}$ & $-91.61^{* * *}$ \\
& $(2.122)$ & $(5.563)$ & $(11.97)$ & $(0.0109)$ & $(1.181)$ \\
Constant & $39.28^{* * *}$ & $504.8^{* * *}$ & $459.8^{* * *}$ & $0.257^{* * *}$ & $121.2^{* * *}$ \\
& $(2.313)$ & $(6.281)$ & $(14.03)$ & $(0.0128)$ & $(1.374)$ \\
\hline \hline Nb. Ind & 334,754 & 334,754 & 334,754 & 334,754 & 334,754 \\
Nb. Obs & $1,339,016$ & $1,339,016$ & $1,339,016$ & $1,339,016$ & $1,339,016$
\end{tabular}

Notes: 2473 persons enter or leave Alsace Moselle, contributing to the estimation of the impact of the Alsace Moselle local system. Dependent variables: dentist denotes the annual amount repaid by the national health insurance for dentists visits, doctor denotes the amounts repaid for doctors (general practitioners and specialists), drugs denotes the amount repaid for prescription drugs, sick-leave denotes the number of periods of sick-leave, sickdays denotes the annual number of sick-leave days. Additional controls included: years fixed effects, and controls for the effect moving. Standard errors are clustered at the individual level.

Table 4 presents the results of the estimation for expenditures for dentist visits, doctor visits (including general and specialist physicians), the number of periods of sick-leave, and the total number of sick days. In the first column, the explained variable is the annual expenditures for dental care repaid by national insurance for expenditures of individual i. 
Working in Alsace Moselle has a significant impact on this amount. The national insurance repays on average 5.3 euros more for dental expenditures when the movers are in Alsace Moselle compared to when they are in the rest of France, holding all else constant. The effect is a $10 \%$ increase, as the average annual dental care consumption of movers is around 50 euros (Table 3).

The treatment effect on annual expenditures for doctor visits repaid by national insurance is not significant (Table 4). People moving in and out of the Alsace Moselle local regime do not change their level of expenditures for doctor visits (including general practitioners and specialists) when they are subject to higher reimbursement rates.

When affiliated to the local system, individuals decrease their consumption of prescription drugs by about 20 euros per year. The effect represents about $14 \%$ of annual expenditures, if we compare it to the value in Table 3. People consume less drugs when they are in Alsace Moselle, subject to higher public reimbursement rates.

The possible underlying mechanisms of such a decrease in consumption will be discussed in details in the next Section.

When working in Alsace Moselle, people take 2.7\% more sick-leave periods of more than three days (Table 4). The effect is only significant at $10 \%$. This is a $9 \%$ increase, as people changing their place of work take on average 0.30 sick-leave periods of more than three days per year (Table 3). The effect on the total number of sick-leave days is not significant. Individuals do not have more sick-leave days in total when subject to a more generous sick-leave policy.

To interpret our results, one has to keep in mind that we do not assess the impact of an increase of total reimbursement rate, but rather an impact of a change in the part reimbursed by public insurance. 


\subsection{Interpretation of the results}

We now present some suggestions we can make from the results, about what are the mechanisms driving the changes in consumption, and about the cost of the local regime for the national insurance. First, the results do not support the presence of moral hazard effects on the public reimbursement rate, and suggest that substitution effects happen. Some results indicate that complementary private insurance matters in explaining the results, through its interaction with the reimbursement rates of public insurance. Having a public complementary insurance in one particular region could be costly for national insurance, if people consume more in this region. It is not the case here, where people consume less care in Alsace Moselle, so there is no additional costs for the national insurance.

\subsubsection{Unmet needs and moral hazard}

In this section, we will not consider non compulsory complementary insurances, and talk instead about moral hazard induced by the presence of a public insurance only. The role of complementary insurances will be discussed in the next section. According to economic theory, more generous reimbursement rates should lead to higher expenditures. We can interpret this impact as a moral hazard effect, negative for public welfare. As the price is low, people over-consume health care, they consume more health care than the socially efficient level. Unmet medical needs can explain the same empirical result, and imply opposite conclusions concerning welfare. If people do not spend enough on health care, this can have adverse effects on a population's health, because of externalities in health care consumption, and on future health spending if preventive care is neglected. Therefore, releasing financial constraints on health spending could improve welfare.

We studied the impact of lower prices on the consumption of various health items. Moral hazard and unmet needs are likely to impact particularly different items, so we can use the heterogeneity in the impacts to try to understand what is driving the changes 
in consumption. Dental care expenditures greatly depend on income, and inequalities in access to dental care are sizeable. Dental care is the first type of health care that is cited when people are asked about unmet needs for financial reasons, as Fantin et al. (2012) explain. In France, drug expenditures are particularly high (Sabban \& Courtois (2007)), due to a heavy drug consumption culture. Decreasing drug consumption is an important concern for public policies (Cabut \&. Clavreul (2012)). Dentist expenditures and drug consumption are two areas of expenditure that should typically react to higher public repayment rates, but for different reasons. Moral hazard should impact more drug consumption, and unmet needs would more likely impact dental care, especially for the poorest households. We find an increase in dental care consumption, but a decrease in drug consumption. Those results are not consistent with the hypothesis that increasing public repayment rates for drugs worsens over-consumption and moral hazard.

In our case, total health care expenditures decrease when people are subject to higher public reimbursement rates, considering that the total number of sick-leave days and spending for doctor visits are unaffected and for the subpopulation of movers.

\subsubsection{The drop in drug consumption: substitution effect, regional differences in supply, or complementary insurances?}

We found that people consume less prescription drugs in Alsace Moselle, when facing a higher repayment rate. As other prices of health care decrease too, the drop in prescription drug consumption could be due to substitution effects. The relative price of drugs compared to other health care related goods could be higher in Alsace Moselle, explaining the decrease in consumption. In addition to the drop in drug consumption, being affiliated to a more generous system increases the use of two other health care items: the number of sick-leave periods and dental care. Thus, drug consumption may be substituted for dental care and short sick-leave periods. People in Alsace Moselle would consume less prescription drugs 
because they can consume more dental care and short sick-leave periods, which enables them to take less medicines to treat symptoms like antipyretic or painkillers, for instance. Our results suggest that it is important to take into account substitution between different health care items when measuring the costs of having higher reimbursement rates.

An alternative hypothesis to explain the decrease in drug consumption in Alsace Moselle is the presence of another aspect of the local regime which is unobserved, as differences in the supply of medical care. Our strategy enables us to rule out regional particularities on the demand side, as we compare consumption of the same persons when in and when out of Alsace Moselle. However, local differences on the supply side could drive part of the results. Some differences are investigated in the next Section, namely, the density of physicians and pharmacies. There could also be unobserved differences in doctors practices across regions.

Complementary private insurance plays an important role in some choices related to health consumption, because for some medical items as dental care, the basis of repayment of the national insurance underestimates the real cost. We do not have the level of coverage by complementary insurance in our data. However, we know the average coverage rate by complementary insurance thanks to the Health Care and Insurance Surveys (ESPS), from the Institute for Research and Documentation in the Economics of Health (IRDES). According to ESPS, $85.5 \%$ of individuals working in Alsace have a complementary insurance, while the national average is $87 \%$. On the opposite, $90 \%$ of individuals in Lorraine (which include Moselle) have a complementary insurance. This could explain the differences we observe between Alsace Moselle subregions, documented in the next section. But including the average coverage by complementary insurance at the regional level in our regressions does not affect our coefficients. 


\section{Discussion and robustness check}

\subsection{Validity of the identification method}

We use a difference-in-difference method, the treatment being affiliation to the local system. Individuals from the control group move as well, but do not change their affiliation to the local system. This method relies on the exogeneity of mobility to Alsace Moselle. We will check if this assumption is credible.

\subsubsection{Is mobility exogenous?}

The validity of our method relies on the exogeneity of the choice to move to or from Alsace Moselle. As we use a fixed effect panel data model, mobility does not need to be exogenous to time-invariant individual heterogeneity, but it needs to be uncorrelated to unobserved time-varying characteristics affecting health care expenditures.

If individuals change their place of work to benefit from a more generous system when they anticipate they will have high expenses, our estimates would be positively biased. This could be the case for dental health care consumption or number of sick-leave periods, for which we find a positive impact of higher reimbursement rates. Concerning drugs, we find a negative impact, so if it is biased, the real impact would be a larger negative impact.

To deal with this possible endogeneity, we run the same model, but excluding people who move from or to neighboring areas (namely, Lorraine, or Franchle-Comté). If individuals go to a region far away, this would imply high costs in terms of housing or transport, and moving would be more costly than getting an expensive private insurance with a large reimbursement rate. The differences in reimbursement rates between the Alsace Moselle local system and the French national system only apply to the fraction of expenditures repaid by national insurance, so that the difference between the two public systems is lower than the differences between various private insurances. Excluding individuals who move 
from regions which are close to Alsace Moselle, we keep only moves that are likely to be undertaken for other motives than the reimbursement rates. We select also individuals who move to a region far away in the control group, for the control group to be comparable. 
Table 5: Effects without migrations to neighboring regions

\begin{tabular}{lccccc}
\hline \hline & Dentist & Doctor & Drugs & Sick leaves & Sick days \\
\hline Alsace Moselle & 5.52 & -0.086 & $-24.8^{*}$ & $0.039^{*}$ & 1.35 \\
& $(3.29)$ & $(4.39)$ & $(12.5)$ & $(0.018)$ & $(0.87)$ \\
\hline Nb. Ind & 319,445 & 319,445 & 319,445 & 319,445 & 319,445 \\
Nb. Obs & $1,277,780$ & $1,277,780$ & $1,277,781$ & $1,277,780$ & $1,277,780$ \\
Notes: Significance levels: $*: 10 \%$ & $* *: 5 \%$ & $* * *: 1 \% . \mathrm{N}=319925$ & individuals, \\
including 2196 individuals changing system, t=4 years. Individuals moving to a neighbor- \\
ing region are excluded. Dependent variables: dentist denotes the annual amount repaid \\
by the national health insurance for dentists visits, doctor denotes the amounts repaid for \\
doctors (general practitioners and specialists), drugs denotes the amount repaid for pre- \\
scription drugs, sick-leave denotes the number of periods of sick-leave, sick-days denotes the \\
annual number of sick-leave days. Additional controls included: income, employment status, \\
years fixed effects, and controls for the effect moving. Standard errors are clustered at the \\
individual level.
\end{tabular}


Table 5 presents the results for spending for dentist visits, doctor visits, drug consumption, number of sick-leave periods and total number of days of sick absence, without close migrations.

The results are similar to the previous ones, there is a positive effect of working in Alsace Moselle on dental consumption, of 5.5. It is no longer significant. There is still no effect of expenditures for doctors visits, and a negative effect on drug consumption, which is of -25 , significant at $10 \%$. There is no significant effect on the total number of sick-leave days, and an effect of 0.039 on the number of sick-leave periods, significant at $5 \%$.

The effects are similar to the ones including close migrations, so that the effects observed are not driven by endogenous mobility. The standard errors are larger because the sample of movers contributing to the effect of Alsace Moselle is smaller when excluding movers to neighboring regions.

\subsection{Robustness checks}

In this section, we change the specification of the model to assess its robustness. We change the controls included, add information about health supply, and apply the same model, but only on the population of movers, people who change their region of work at least once. The results obtained using these different specifications are similar to the original results. Table 6 presents the results for each model and health spending outcome.

\subsubsection{Change the controls included}

We add and delete controls about individuals and the region, to test the robustness of the model.

Without time-variant individual characteristics To evaluate the sensitivity of the results to the controls included, we run the same model without controls, except the in- 
Table 6: Effect across directions of the move

\begin{tabular}{l|c|c|c|c|c} 
& Dentist & Doctors & Drugs & Sick-leave & Sick days \\
\hline Baseline model & $5.26^{* *}$ & -1.35 & $-19.8^{* *}$ & $0.027^{*}$ & 0.50 \\
No controls & $(2.67)$ & $(3.75)$ & $(8.71)$ & $(0.015)$ & $(0.67)$ \\
& $4.98^{*}$ & -3.49 & $-22.3^{* *}$ & $0.028^{*}$ & 0.034 \\
With chronic diseases at t & $(2.67)$ & $(3.71)$ & $(8.68)$ & $(0.015)$ & $(0.65)$ \\
& $5.26^{* *}$ & -1.48 & $-20.1^{* *}$ & $0.027^{*}$ & 0.56 \\
With health care availability & $(2.67)$ & $(3.74)$ & $(8.63)$ & $(0.015)$ & $(0.67)$ \\
& 4.59 & $-10.8^{* *}$ & $-18.6^{* *}$ & -0.00069 & $-2.17^{* * *}$ \\
Only movers & $(2.94)$ & $(4.37)$ & $(9.11)$ & $(0.016)$ & $(0.76)$ \\
& $5.27^{* *}$ & -2.74 & $-21.0^{* *}$ & $0.025^{*}$ & 0.054 \\
& $(2.66)$ & $(3.70)$ & $(8.70)$ & $(0.015)$ & $(0.64)$ \\
\hline
\end{tabular}

Significance levels: $*: 10 \% \quad * *: 5 \% \quad * * *: 1 \%$. Standard errors are shown in parentheses. $\mathrm{Nb}$ Ind $=334754, \mathrm{t}=4$ years. Only movers: $\mathrm{Nb}$ Ind $=35176, \mathrm{t}=4$ years. With health are availability, we exclude 24 individuals for whom we do not have information about health care availability at the county of work. $\mathrm{Nb}$ Ind $=334,754$. Physicians and pharmacies densities are used as proxies for health care availability. Sick-leave: number of periods of sick-leave. Sick-days: total number of sick-leave days

dividual fixed effect. The results of the estimations for dentist visits, doctor visits, drug consumption, number of sick-leave periods and number of sick leave days are presented in row two of Table 6 . We can compare them with the results of the baseline model (with the controls), on row one.

The effect of working in Alsace Moselle on dental consumption is now significant at $10 \%$, and the magnitude is close to the previous result. Concerning expenditures linked to doctor visits, it is still not significant. Drug consumption is significant at $5 \%$, the effect is -22. The effect on the number of sick-leave periods is still 0.03 , significant at $10 \%$. The total number of sick-leave days is still not significant.

Adding information about chronic diseases We have one aspect of health status in our data, whether the individual is registered as having a chronic disease. We consider the diseases for which the public insurance reimbursement rate is $100 \%$. We did not add chronic diseases in our baseline model, because having a chronic disease at time $t$ could 
be endogenously related to a low level of consumption of health care until $t$. For the same reason, including chronic diseases at $t-1$ is at best only weakly exogenous. However, results in Table 6 show that our main results are not sensible to the inclusion of such dummies.

Add medical professions density We run the same model, adding medical profession density as controls. We did not add medical density in our main model, because we think density can be endogenous to the demand in the long run. Indeed, if demand is higher in a region, it it likely that supply will adapt. Medical density would be impacted by changes in consumption.

However, our effect could be due to change in supply of care among regions. We want to check if the effect does not vanish when taking into account variability in dentists density, doctors density and pharmacies density.

Both access to health care and induced demand can depend on physician density. Physicians who have less patients because of high density can be willing to increase demand to maintain their income. Density also increases competition between physicians, which can decrease the price of health care. Higher density also decreases the cost of medical care use through the reduction of the average distance of each person to the closest dentist or doctor. Physicians density is high in Alsace Moselle, and pharmacies density is low. Therefore, density of physicians and pharmacies could explain our results, higher expenditures for dentists, lower for drugs.

We run the same model adding doctors density and in each department in $2009^{7}$. We do not add doctors who are specialists and dentists because more than $85 \%$ of the variation of their density across regions is explained by pharmacies density and general

\footnotetext{
${ }^{7}$ Information about density is at the department level, from public statistics from the Direction de la recherche, des études, de l'évaluation et des statistiques Source : http://www.drees.sante.gouv.fr/IMG/apps/statiss/default.htral
} 
practitioners density. A model with the four densities used in the $X$ does not change a lot the coefficients but increases substantially the estimated standard errors, reflecting high degrees of correlation of the four densities.

Row three of table 6 presents the results with physicians density. The coefficient on dental care use is now not significant. The effect on drug consumption is still significant at $5 \%$. Both coefficients are smaller than before, but similar. Coefficients on annual number of sick days and spending for doctor visits are now significant at $5 \%$, and negative. Working in Alsace Moselle decreases the use of doctor visits and sick days, holding health care availability constant. The effect is -11 euros for doctor visits, and two days less of sick-leave per year. The impact of the number of sick-leave period is not significant. The provocative results of a lower consumption of drugs when the public repayment rate is higher cannot be explained simply by the supply side. On the contrary, taking into account the density of physicians and pharmacies leads to even more provocative results!

\subsection{Placebo tests}

We found an effect of changing the place of work on dental care consumption, and drug consumption in Alsace Moselle.

We run the same model on each region, except Corse, and overseas departments. This leaves all 21 regions of mainland France, except Alsace Moselle. On average, if there is zero effect of those regions, we should find approximately one region significant at $5 \%$, and one at $10 \%$, for each outcome. The Lorraine region includes Moselle, so we replace it by a region including all subregions of Lorraine but Moselle.

For dental care, two regions have a significant impact, Haute-Normandie, effect of -4.8, significant at 5\%, and Pays de la Loire, effect of 3.1, significant at 10\%. Concerning drug consumption, there is a significant effect in three regions. Two are significant at $5 \%$ : Pays de la Loire, effect of -23.5 and Provence-Alpes-Cote d'Azur, effect of 27.4. One is 
significant at $10 \%$ : Lorraine but Moselle (16.7).

Given that a no impact would result in two significant regions (at 10\%) for each item, and we get two regions for dental care, three for drug consumption, our placebos tests are consistent with the hypothesis that other regions than Alsace Moselle do not impact consumption.

We use another way to have better insight to whether the effects we observed are due to regional particularities or to the local regime. We perform the same model, but using people who change their place of living, not their place of work. The correlation between changing the place of work and the place of residence is quite low, around 0.35 . As being affiliated to the local system is correlated with the living in the region Alsace Moselle, we want to assess if the effect are indeed due to working in Alsace Moselle and not to living in Alsace Moselle. We estimate the impact of moving to Alsace Moselle only for individuals who do not change their affiliation to the local system, that is, who do not change their place of work. Table 7 presents the results of this estimation.

Table 7: Effect of living in Alsace Moselle on medical care use

\begin{tabular}{lccccc}
\hline \hline & Dentist & Doctor & Drugs & Sick leaves & Sick days \\
\hline Alsace Moselle & 4.843 & 4.110 & 1.501 & $-0.0587^{*}$ & -0.475 \\
& $(5.570)$ & $(10.11)$ & $(9.319)$ & $(0.0317)$ & $(1.260)$ \\
\hline \hline Nb. Ind & 332,281 & 332,281 & 332,281 & 332,281 & 332,281 \\
Nb. Obs & $1,329,124$ & $1,329,124$ & $1,329,124$ & $1,329,124$ & $1,329,124$ \\
Notes: Significance levels: $\quad *: 10 \%$ & $* *: 5 \%$ & $* * *: 1 \%$. We exclude individuals who \\
change their affiliation to the local system from those regressions. 1005 individuals change \\
their place of living from or to Alsace Moselle, without entering or leaving the local system \\
(either always or never working in Alsace Moselle). Dependent variables: dentist denotes the \\
annual amount repaid by the national health insurance for dentists visits, doctor denotes the \\
amounts repaid for doctors (general practitioners and specialists), drugs denotes the amount \\
repaid for prescription drugs, sick-leave denotes the number of periods of sick-leave, sick- \\
days denotes the annual number of sick-leave days. Additional controls included: income, \\
employment status, years fixed effects, and controls for the effect moving. Standard errors \\
are clustered at the individual level.
\end{tabular}

The result for dental care consumption is similar (4.8), but not significant. The effect on drug consumption (-1.5) is much lower, and no longer significant. There is an impact 
of working in Alsace Moselle on drug consumption, but living in Alsace Moselle has no impact. It seems that it is being affiliated to the local system that matters, not local particularities as differences in supply of care, which would impact people living in Alsace Moselle as much as people working in Alsace Moselle. The impact on the number of sickleave periods is now just significant for a level of $10 \%$ and negative. The impact on the number of sick-leave days and doctors visits, is, as before, non significant.

\subsection{Decomposing the effects}

We evaluate how the effects on medical care use vary depending on direction of the move (from Alsace Moselle, to Alsace Moselle, and going back and forth), depending on the subregion of Alsace Moselle concerned by the move (Haut-Rhin, Bas-Rhin or Moselle), and depending on individual characteristics. Results can be found in Appendix B on page 44

Across directions of the move, and subregions The significance of the effects is not similar across groups. The magnitudes of the coefficients vary, but the difference between them is not significant, due to large standard errors. The signs of the coefficients are similar across both direction of the move and across Alsace Moselle subregions.

Across individual characteristics To have more insight about the interpretation of our effect and to see if some particular groups of people drive the average impact we measure, we evaluate how the effects vary with individual characteristics. We interact time-invariant characteristics with working in Alsace Moselle. We run models to see how our effect varies with four main characteristics: health status (chronic diseases), age, gender and income. To summarize, the effect on drugs is higher for males, for persons with chronic diseases, for persons older than forty and for high incomes. But this analysis is conducted separately 
for each variable, and because these variables are positively correlated (at least for age, male and incomes) it is not clear to determine which of them drives the heterogeneity of the effect of the treatment.

\subsection{Effects on other measures of health care consumption}

To evaluate the effects of changes in total expenses for medical care, we use total expenditures for health care as dependent variables, instead of only the part repaid by the national insurance. Table 8 presents the results.

Table 8: Effect of the Alsace Moselle local system on medical care use

\begin{tabular}{lccc}
\hline \hline & Dentist & Doctor & Drugs \\
\hline Alsace Moselle & $17.43^{*}$ & -0.601 & $-21.02^{* *}$ \\
& $(10.55)$ & $(5.485)$ & $(9.118)$ \\
\hline \hline Nb. Ind & 334,754 & 334,754 & 334,754 \\
Nb. Obs & $1,339,016$ & $1,339,016$ & $1,339,016$ \\
Notes: Significance levels: * $* 10 \% \quad * *: 5 \%$ & $* * *: 1 \%$. \\
2473 individuals enter or leave Alsace Moselle. & Dependent vari- \\
ables: dentist denotes the annual amount spent for dentists visits, \\
doctor denotes the amount spent for doctors (general practition- \\
ers and specialists), drugs denotes the amount spent for prescrip- \\
tion drugs, sick-leave denotes the number of periods of sick-leave. \\
Additional controls included: income, employment status, years \\
fixed effects, and controls for the effect moving. Standard errors \\
are clustered at the individual level.
\end{tabular}

Concerning expenditures for dental care, the coefficient is no longer significant at $5 \%$, and it is higher than the value for the part repaid. The effect on doctor visit expenditures is not significant. The effect on drug expenditures is -21 , significant at $5 \%$.

\section{Conclusion}

We assess whether moving to a region where the public health insurance is more generous impacts individual medical care expenditures, using an administrative panel dataset. 
Regressing health expenditures on the public insurance system, controlling for individual fixed effects, we find that individuals moving to a region with higher public reimbursement rates do not consume more care. We argue that reimbursement rates of the public health insurance are not decisive factors affecting medical care use in France, at least for a specific population of movers.

\section{References}

Akerlof, G. A. (1970), "The market for "lemons": Quality uncertainty and the market mechanism', The Quarterly Journal of Economics 84(3), 488-500.

Beck, R. G. (1974), 'The effects of co-payment on the poor', Journal of Human Ressources $9(1), 129-42$.

Buchmueller, T. C., Couffinhal, A., Grignon, M. \& Perronnin, M. (2004), 'Access to physician services: does supplemental insurance matter? evidence from france', Health Economics 13(7), 669-687.

Cabut, S. \& Clavreul, L. (2012), 'La consommation pharmaceutique a connu une baisse inédite de 0,8 points en 2011', Le Monde.

Chemin, M. \& Wasmer, E. (2008), "Regional Difference-in-Differences in France Using the German Annexation of Alsace-Moselle in 1870-1918", University of Chicago Press, pp. 285-305.

Chemin, M. \&. Wasmer, E. (2009), 'Using alsace-moselle local laws to build a differencein-differences estimation strategy of the employment effects of the 35-hour workweek regulation in france', Journal of Labor Economics 27(4), 487-524. 
Chiappori, P.-A., Durand, F. \&. Geoffard, P.-Y. (1998), 'Moral hazard and the demand for physician services: First lessons from a french natural experiment', European Economic Review 42(3-5), 499-511.

Chiappori, P.-A., Jullien, B., Salanié, B. \&. Salanié, F. (2006), 'Asymmetric information in insurance: general testable implications', RAND Journal of Economics 37(4), 783-798.

Chiappori, P.-A. \& Salanié, B. (2000), 'Testing for asymmetric information in insurance markets', Journal of Political Economy 108(1), 56-78.

Cours des Comptes (2011), "le régime d'assurance maladie complementaire obligatoire d'alsace-moselle", Technical report, Cours des Comptes.

Einav, L. \&. Finkelstein, A. (2011), 'Selection in insurance markets: Theory and empirics in pictures', Journal of Economic Perspectives 25(1), 115-138.

Einav, L., Finkelstein, A., Ryan, S. P., Schrimpf, P. \&. Cullen, M. R. (2013), 'Selection on moral hazard in health insurance', American Economic Review 103(1), 178-219.

Fantin, R., Jusot, F. \& Dourgnon, P. (2012), Payer peut nuire à votre santé : une étude de l'impact du renoncement financier aux soins sur l'état de santé, Technical report.

Finkelstein, A. (2007), 'The aggregate effects of health insurance: Evidence from the introduction of medicare', The Quarterly Journal of Economics 122(1), 1-37.

Finkelstein, A. \& Poterba, J. (2006), Testing for asymmetric information using 'unused observables' in insurance markets: Evidence from the u.k. annuity market, Nber working papers, National Bureau of Economic Research, Inc.

Finkelstein, A., Taubman, S., Wright, B., Bernstein, M., Gruber, J., Newhouse, J. P., Allen, H., Baicker, K. \& the Oregon Health Study Group (2012), 'The oregon health 
insurance experiment: Evidence from the first year', The Quarterly Journal of Economics $\mathbf{1 2 7}(3), 1057-1106$.

Halima, M. A. B., Debrand, T. \&. Regaert, C. (2011), Arrêts maladie : comprendre les disparités départementales, Working papers, IRDES institut for research and information in health economics.

Imbens, G. W. \& Angrist, J. D. (1994), 'Identification and estimation of local average treatment effects', Econometrica 62(2), 467-475.

Jones, A. M., Koolman, X. \& Doorslaer, E. V. (2006), 'The impact of having supplementary private health insurance on the uses of specialists', Annales d'Economie et de Statistique (83-84), 251-275.

Jullien, B., Salanié, B. \&. Salanié, F. (2007), 'Screening risk-averse agents under moral hazard: single-crossing and the cara case', Economic Theory 30(1), 151-169.

Keeler, E. B. \&. Rolph, J. E. (1988), 'The demand for episodes of treatment in the health insurance experiment', Journal of Health Economics 7, 337-367.

Manning, W. G., Newhouse, J. P., Duan, N., Keeler, E. B. \&. Leibowitz, A. (1987), 'Health insurance and the demand for medical care: Evidence from a randomized experiment', American Economic Review 77(3), 251-77.

Million, A., Riphahn, R. T. \&. Wambach, A. (2003), 'Incentive effects in the demand for health care: a bivariate panel count data estimation', Journal of Applied Econometrics 18(4), 387-405.

Phelps, C. E. \& Newhouse, J. P. (1972), 'Effect of coinsurance: a multivariate analisys', Social Security Bulletin . 
Rothschild, M. \& Stiglitz, J. (1976), 'Equilibrium in competitive insurance markets: an essay on the economics of imperfect information', The Quarterly Journal of Economics $90(4), 629-649$.

Sabban, C. \& Courtois, J. (2007), 'Comparaisons européennes sur huit classes de médicaments', Points de repère (12).

Schokkaert, E., Ourti, T. V., Graeve, D. D., Lecluyse, A. \& de Voorde, C. V. (2010), 'Supplemental health insurance and equality of access in belgium', Health Economics 19(4), 377-395.

Scitovsky, A. A. \& McCall, N. M. (1977), 'Coinsurance and the demand for physician services: Four years later', Social Security Bulletin .

Scitovsky, A. A. \&. Snyder, N. M. (1972), 'Effect of coinsurance on use of physician services', Social Security Bulletin .

Spence, M. (1973), 'Job market signaling', The Quarterly Journal of Economics 87(3), 355374.

Wooldridge, J. M. (2002), Econometric Analysis of Cross Section and Panel Data, The MIT Press. 


\section{A Details about the local system}

Table 9: Definition of the variables used in the model

\begin{tabular}{|c|c|c|c|c|}
\hline $\begin{array}{l}\text { Type of } \\
\text { variable }\end{array}$ & Variable & Definition & Default value & Mean \\
\hline $\begin{array}{l}\text { Variable of } \\
\text { interest }\end{array}$ & $\begin{array}{l}\text { Alsace } \\
\text { Mloselle }\end{array}$ & $\begin{array}{l}\text { dummy equal to one if the individual } \\
\text { works in Alsace Moselle }\end{array}$ & $\begin{array}{l}\text { works in the } \\
\text { rest of France }\end{array}$ & 0.045 \\
\hline \multirow{3}{*}{$\begin{array}{l}\text { Time dum- } \\
\text { mies }\end{array}$} & year 2006 & year of the observation is 2006 & year 2005 & - \\
\hline & year 2007 & year of the observation is 2007 & year 2005 & - \\
\hline & year 2008 & year of the observation is 2008 & year 2005 & - \\
\hline \multirow[t]{5}{*}{$\begin{array}{l}\text { About } \\
\text { moving }\end{array}$} & $\begin{array}{l}2 \text { years be- } \\
\text { fore moving }\end{array}$ & $\begin{array}{l}\text { year of the observation is } 2 \text { years before } \\
\text { the person changes her region of work }\end{array}$ & $\begin{array}{l}3 \text { years before } \\
\text { or not moving }\end{array}$ & 0.021 \\
\hline & $\begin{array}{l}\text { year before } \\
\text { moving }\end{array}$ & $\begin{array}{l}\text { year of the observation is the year be- } \\
\text { fore the person changes her region of } \\
\text { work }\end{array}$ & $\begin{array}{l}3 \text { years before } \\
\text { or not moving }\end{array}$ & 0.035 \\
\hline & $\begin{array}{l}\text { year after } \\
\text { moving }\end{array}$ & $\begin{array}{l}\text { year of the observation is the year after } \\
\text { the person changes her region of work }\end{array}$ & $\begin{array}{l}3 \text { years before } \\
\text { or not moving }\end{array}$ & 0.035 \\
\hline & $\begin{array}{l}2 \text { years af- } \\
\text { ter moving }\end{array}$ & $\begin{array}{l}\text { year of the observation is } 2 \text { years after } \\
\text { the person changes her region of work }\end{array}$ & $\begin{array}{l}3 \text { years before } \\
\text { or not moving }\end{array}$ & 0.024 \\
\hline & $\begin{array}{l}3 \text { years af- } \\
\text { ter moving }\end{array}$ & $\begin{array}{l}\text { year of the observation } 3 \text { years after the } \\
\text { person changes her region of work }\end{array}$ & $\begin{array}{l}3 \text { years before } \\
\text { or not moving }\end{array}$ & 0.013 \\
\hline \multirow[t]{2}{*}{$\begin{array}{l}\text { Current } \\
\text { situation }\end{array}$} & unemployed & $\begin{array}{l}\text { the individual spent } 4 \text { terms unem- } \\
\text { ployed during the year }\end{array}$ & did not & 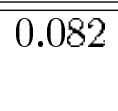 \\
\hline & $\begin{array}{l}\text { partly un- } \\
\text { employed }\end{array}$ & $\begin{array}{l}\text { the individual spent between } 1 \text { and } 3 \\
\text { terms unemployed during the year }\end{array}$ & $\begin{array}{l}\text { work, or no } \\
\text { information }\end{array}$ & 0.073 \\
\hline \multirow[t]{2}{*}{ Wage } & log income & $\begin{array}{l}\text { logarithm of annual income, including } \\
\text { pensions, equal to } 0 \text { if the individual } \\
\text { has a zero income }\end{array}$ & - & 9.2 \\
\hline & $\begin{array}{l}\text { income } \\
\text { dummy }\end{array}$ & dummy for having a zero income & $\begin{array}{l}\text { non zero in- } \\
\text { come }\end{array}$ & 0.059 \\
\hline
\end{tabular}




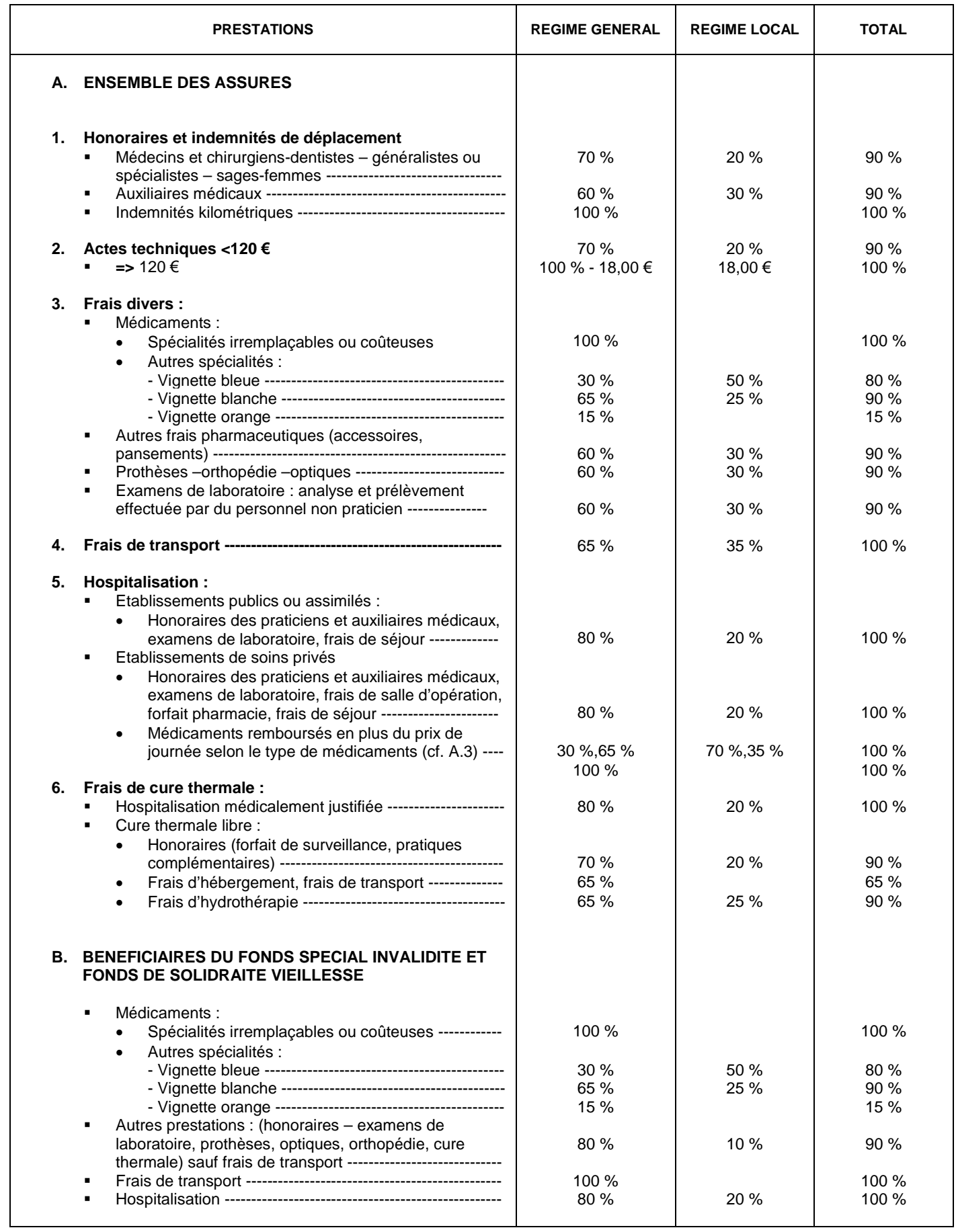

Figure 1: Part of expenditures repaid by the national regime, part repaid by the local regime, and total public repayment rate for someone affiliated to the local regime 


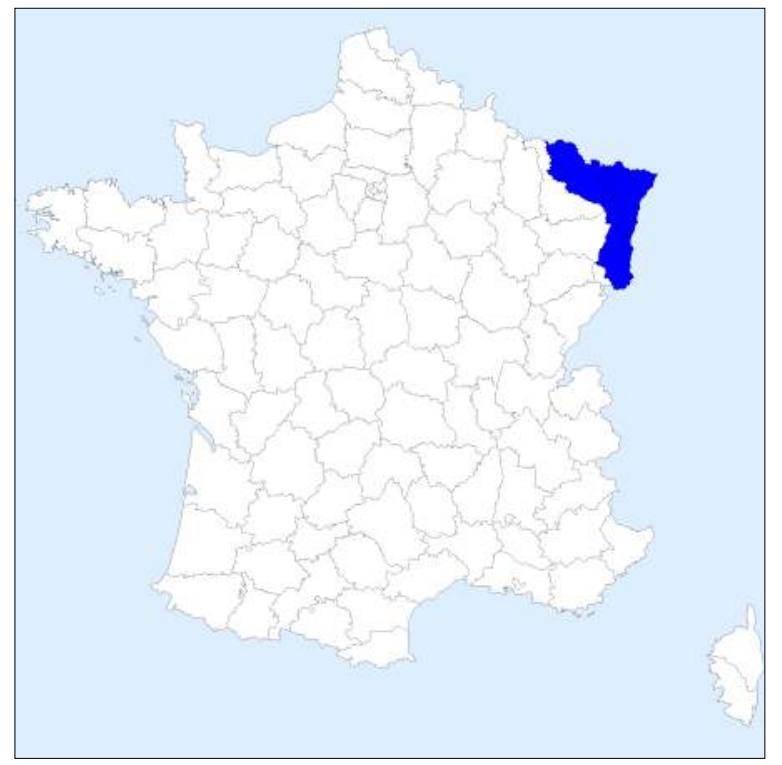

Figure 2: The Alsace Moselle region.

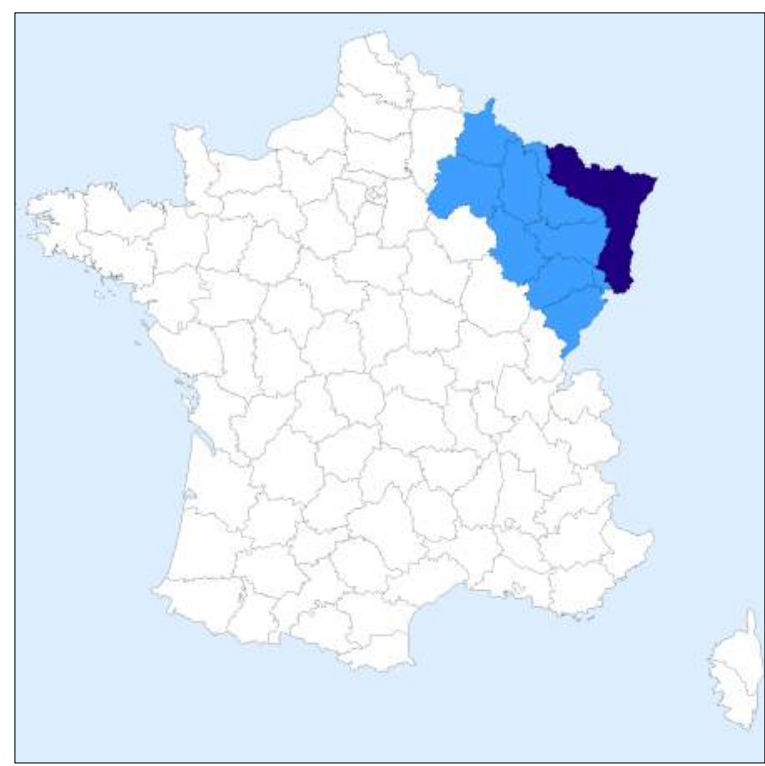

Figure 3: The Alsace Moselle region, and departments less than $100 \mathrm{~km}$ away 


\section{B Decomposing the effects}

\section{B.1 Across the direction of the migration}

We want to check if the effect of being in Alsace Moselle is symmetrical for people entering and leaving the Alsace Moselle local regime.

To evaluate whether this is the case, we split people moving into three groups: the ones moving from Alsace Moselle $(\mathrm{N}=1059)$, the ones moving to Alsace Moselle $(\mathrm{N}=874)$, and the ones who both enter and leave the system during the period $(\mathrm{N}=540)$. Belonging to each group is time-invariant. Each group spends approximately half of the period in Alsace Moselle. The model is the following:

$$
\begin{aligned}
y_{i t}=\beta_{1} \text { Entering }_{i} * \mathrm{AM}_{i t}+\beta_{2} \text { Leaving }_{i} * \mathrm{AM}_{i t}+\beta_{3} \text { Back and forth } & * \mathrm{AM}_{i t} \\
& +\sum_{k=-3}^{2} \delta_{k} w_{k i t}+\gamma x_{i t}+\phi_{t}+\alpha_{i}+\varepsilon_{i t},
\end{aligned}
$$

Then, we measure the effect of working in Alsace Moselle for each group. We include the same controls as in the previous model. Instead of having a single parameter measuring the effect of working in Alsace Moselle regardless of the direction of the move, there are now three distinct effects: working in Alsace Moselle, for someone who leaves Alsace Moselle during the period, working in Alsace Moselle, for someone who enters Alsace Moselle during the period, and working in Alsace Moselle, for someone going back and forth (entering and leaving at least once during the period). We want to test whether the three coefficients $\left(\beta_{1}\right.$, $\beta_{2}$ and $\beta_{3}$ ) are significantly different, for each outcome considered (dentist visits, doctor visits, drug consumption, number and duration of sick-leave periods). Table 10 presents the results.

For all outcomes, the difference between $\beta_{1}, \beta_{2}$ and $\beta_{3}$ is not significant, due to the large standard errors. There is a positive effect on dentist visits for the three groups, it is never 
the three departments of Alsace Moselle: Haut-Rhin, Bas-Rhin and Moselle. The model is the following:

$$
y_{i t}=\beta_{1} \text { Haut-Rhin }_{i t}+\beta_{2} \text { Bas-Rhin }_{i t}+\beta_{3} \text { Moselle }_{i t}+\sum_{k=-3}^{2} \delta_{k} w_{k i t}+\gamma x_{i t}+\phi_{t}+\alpha_{i}+\varepsilon_{i t}
$$

Here, people changing the subregion of work but staying in Alsace Moselle (moving from Moselle to Haut-Rhin for instance) contribute to the estimation. Table 11 presents the coefficients on each subregion of Alsace Moselle, and a test of quality of those coefficients, for each outcome.

For every outcome, the effects are not significantly different. The effects are all positive for dentists visits, and significant for Haut-Rhin only. The effects are either positive or negative for doctor visits, and the difference between them is not significant. The effects on prescription drug use are all negative. The effect is significant for Haut-Rhin and Bas-Rhin. The effects on sick-leave periods are all positive. The effects on the number of sick-leave days are either positive or negative.

\section{B.3 Across individual characteristics}

We assess whether some groups of people drive the effects we measure.

To have more insight about the interpretation of our effect, we evaluate how the effects vary with individual characteristics, and to see if some particular groups of people drive the average impact we measure. We interact time-invariant characteristics with working in Alsace Moselle, for our coefficient to measure the effect of Alsace Moselle on medical care use for each group. The composition of groups is time-invariant. We run models to see how our effect varies with four main characteristics: health status (chronic diseases), age, gender and income. 
Table 11: Effect across Alsace Moselle subregions

\begin{tabular}{|c|c|c|c|c|c|}
\hline & Dentist & Doctors & Drugs & Sick-leave & Sick days \\
\hline hautrhin & $\begin{array}{l}9.36^{* *} \\
(4.65)\end{array}$ & $\begin{array}{l}-7.63 \\
(5.83)\end{array}$ & $\begin{array}{c}-20.8^{* *} \\
(10.2)\end{array}$ & $\begin{array}{c}0.027 \\
(0.027)\end{array}$ & $\begin{array}{l}-0.40 \\
(1.08)\end{array}$ \\
\hline basrhin & $\begin{array}{c}1.22 \\
(4.10)\end{array}$ & $\begin{array}{l}-6.51 \\
(5.15)\end{array}$ & $\begin{array}{c}-33.4^{* *} \\
(16.7)\end{array}$ & $\begin{array}{c}0.030 \\
(0.020)\end{array}$ & $\begin{array}{l}0.092 \\
(0.96)\end{array}$ \\
\hline moselle & $\begin{array}{l}6.69^{*} \\
(3.59)\end{array}$ & $\begin{array}{l}9.87^{*} \\
(5.60)\end{array}$ & $\begin{array}{l}-4.63 \\
(6.74)\end{array}$ & $\begin{array}{c}0.033 \\
(0.022)\end{array}$ & $\begin{array}{l}1.94^{*} \\
(1.03)\end{array}$ \\
\hline Test & 0.26 & 0.039 & 0.12 & 0.99 & 0.23 \\
\hline Nb. Ind & 334,754 & 334,754 & 334,754 & 334,754 & 334,754 \\
\hline Nb. Obs & $1,339,016$ & $1,339,016$ & $1,339,016$ & $1,339,016$ & $1,339,016$ \\
\hline \multicolumn{6}{|c|}{$\begin{array}{l}\text { Significance levels: } \quad *: 10 \% \quad * *: 5 \% \quad * * *: 1 \% .895 \text { individuals enter or } \\
\text { leave Haut-Rhin. } 1,375 \text { individuals enter or leave Bas-Rhin. } 1,166 \text { individuals enter } \\
\text { or leave Moselle. Standard errors are shown in parentheses. Test:p-value of testing } \\
\text { equality of the three coefficients }\end{array}$} \\
\hline
\end{tabular}

Health status We split the sample between individuals registered as having at least one chronic disease during the four years, and individuals never suffering from chronic disease. Then, we measure the impact of working in Alsace Moselle for those two subgroups. The model we estimate is the following:

$$
y_{i t}=\beta_{1} \mathbb{1}_{\text {(Chronic disease) } i} * \mathrm{AM}_{i t}+\beta_{2} \mathbb{1}_{\text {(No chronic disease }) i} * \mathrm{AM}_{i t}+\sum_{k=-3}^{2} \delta_{k} w_{k i t}+\gamma x_{i t}+\phi_{t}+\alpha_{i}+\varepsilon_{i t}
$$

For drug consumption, the impact is much higher for individuals having at least one chronic disease during the period. It is -220 , significant at $5 \%$, whereas it is -2 , not significant, for individuals having no chronic disease along the four years. Concerning dental care, effects are more alike, for individuals with chronic disease, it is 7.6, not significant, for individual with no chronic disease, it is 5.1 , significant at $10 \%$. 
Age We split the sample of movers who enter or leave Alsace Moselle into five groups of equal size, based on their average age across the four years. Our group of movers from or to Alsace Moselle is made of individuals who are, on average, between 25 and 70 . This leads to five groups of equal size, from 25 to 28 , from 29 to 33 , from 34 to 39 , from 40 to 46, and from 47 to 70 . The model we estimate is the following:

$$
\begin{aligned}
y_{i t}=\beta_{1} \mathbb{1}_{(25 \text { to } 28) i} * \mathrm{AM}_{i t}+\beta_{2} \mathbb{1}_{(29 \text { to } 33) i} * \mathrm{AM}_{i t}+\beta_{3} \mathbb{1}_{(34 \text { to } 39) i} * \mathrm{AM}_{i t}+\beta_{4_{t}} \mathbb{1}_{(40 \text { to } 46) i} * \mathrm{AM}_{i t} \\
+\beta_{5} \mathbb{1}_{(47 \text { to } 70) i} * \mathrm{AM}_{i t}+\sum_{k=-3}^{2} \delta_{k} w_{k i t}+\gamma x_{i t}+\phi_{t}+\alpha_{i}+\varepsilon_{i t}
\end{aligned}
$$

The coefficients of interest, $\beta_{1}, \beta_{2}, \beta_{3}, \beta_{4}$ and $\beta_{5}$, measure the impact of working in Alsace Moselle, for individuals of different ages. As our coefficient on age is time-invariant, the coefficients of interest do not capture the impact of average age itself, which is in the fixed-effect. The impact of the Alsace Moselle local system is concentrated among older individuals (over 40 ). None of the $\beta$ are significant at $5 \%$, but the p-value for older individual is lower $(0.089$ and 0.123$)$ than for younger ones $(0.368,0.421$ and 0.568$)$. The coefficients are higher for older individuals $(-44$ and $-5 i)$ than younger ones $(-5,5$ and -8). Detailed results are available upon request. For dental care, results are concentrated among individuals older than 47 , for whom it is significant at $1 \%$. The coefficient is the highest (19) for individuals older than 47. The other coefficients are not significant, there magnitude is between -4 and 7 .

Gender We run the following model.

$$
y_{i t}=\beta_{1} \mathbb{1}_{\text {women } i} * \mathrm{AM}_{i t}+\beta_{2} \mathbb{1}_{\mathrm{Men} i} * \mathrm{AM}_{i t}+\sum_{k=-3}^{2} \delta_{k} w_{k i t}+\gamma x_{i t}+\phi_{t}+\alpha_{i}+\varepsilon_{i t}
$$


We find that effect on drug consumption is higher for men ( -27 , versus -8 for women). It is significant for men only. Effect on dental care consumption is similar for men and women (4.7 and 6.1), and not significant.

Income We run the following model

$$
\begin{aligned}
& y_{i t}=\beta_{1} \mathbb{1}_{(0 \text { to } 6,970) i} * \mathrm{AM}_{i t}+\beta_{2} \mathbb{1}_{(6,971 \text { to } 12,850) i} * \mathrm{AM}_{i t}+\beta_{3} \mathbb{1}_{(12,851 \text { to } 19,005) i} * \mathrm{AM}_{i t} \\
& +\beta_{4 i} \mathbb{1}_{(19,006 \text { to } 28,159) i} * \mathrm{AM}_{i t}+\beta_{5} \mathbb{1}_{(28,160 \text { to } 2,705,054) i} * \mathrm{AM}_{i t} \\
& +\sum_{k=-3}^{2} \delta_{k} w_{k i t}+\gamma x_{i t}+\phi_{t}+\alpha_{i}+\varepsilon_{i t},
\end{aligned}
$$

The impact on drug consumption is concentrated among the richest individuals, who earn above 28,160 euro per year, for whom the coefficient, -72 , is significant at $5 \%$ level. For other groups, the coefficient is not significant. It is between -8 and 0 for individuals earning less than 19,005 euros, and -18 for individuals earning between 19006 and 28159 euros.

Concerning drug consumption, the coefficient is between 3.8 and 7.8 for all groups, it is never significant.

Here, we also present the results on sick-days across levels of income. Indeed, our treatment for sick-days is that in Alsace Moselle, there is no waiting period for allowances, whereas there can be one in the rest of France. Many individuals in the rest of France benefit from coverage by the employed from the first day of sick-leave. This coverage is likely to depend on income, high income benefiting from more generous labor contracts on average. For our estimates to be meaningful, we exclude periods in which individuals are unemployed during the whole year. We find an effect of working in Alsace Moselle on annual number of sick-days for the lower level of income considered (below 6,970), individuals in this group take on average 7.6 more sick-days per year when in Alsace Moselle (significant 
at $5 \%$ ). On the opposite, the coefficients are negative for high income levels (above 19,006), the coefficient are close to -1.5 and p-value around 0.1 for those two groups. For groups with middle income, the coefficients are positive, $\beta_{2}$ is 0.48 and $\beta_{3}$ is 2.4 . 


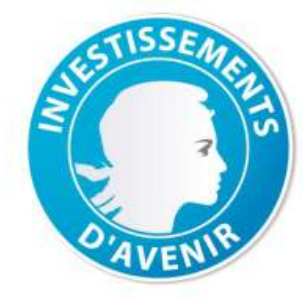

Le LIEPP (Laboratoire interdisciplinaire d'évaluation des politiques publiques) est un laboratoire d'excellence (Labex). Ce projet est distingué par le jury scientifique international désigné par l'Agence nationale de la recherche (ANR). Il est financé dans le cadre des investissements d'avenir. (ANR-11-LABX-0091, ANR-11-IDEX-0005-02)

www.sciencespo.fr/liepp

Directeurs de publication:

Bruno Palier et Etienne Wasmer

Sciences Po - LIEPP

27 rue Saint Guillaume

75007 Paris - France

$+33(0) 1.45 .49 .83 .61$

liepp@sciencespo.fr

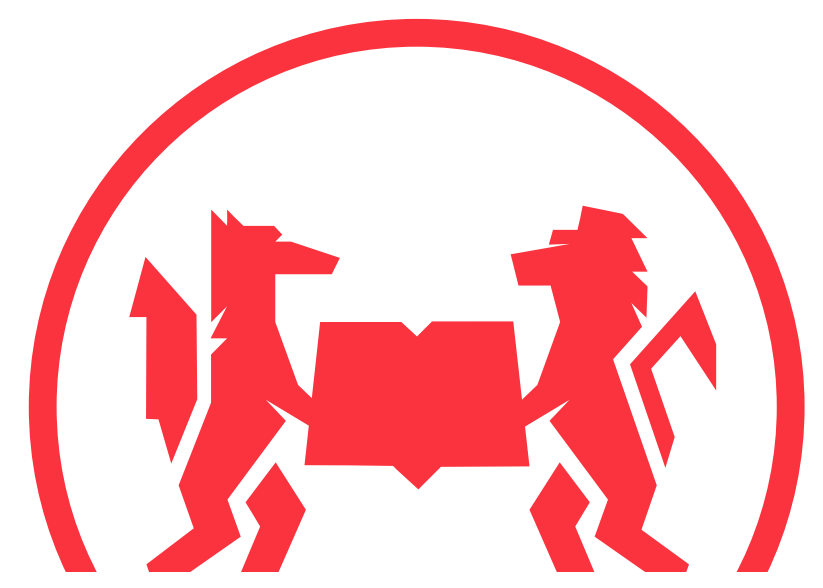

